\title{
Family Farming Cooperatives: the Case of the Mixed Cooperative of Family Farmers of the Ipanema Valley
}

\author{
Gáudia Maria Costa Leite Pereira ${ }^{1}$; João Batista de Oliveira²; Wagner Lins Lira ${ }^{3}$; \\ Jorge Luiz Schirmer de Mattos ${ }^{4}$ \\ ${ }^{1,2}$ Doctoral student, Postgraduate Program in Agroecology and Territotial Development. Federal Rural \\ University of Pernambuco (UFRPE). Recife - Pernambuco - Brazil. \\ ${ }^{3,4}$ Teacher. Postgraduate Program in Agroecology and Territotial Development. Universidade Federal \\ Rural de Pernambuco (UFRPE). Recife - Pernambuco - Brazil.
}

\begin{abstract}
This article addresses cooperativism in the context of family farming, based on the experience of the Cooperativa Mista de Agricultores Familiares do Vale do Ipanema (COOPANEMA) based in the municipality of Águas Belas, Pernambuco, Brazil. This is a reflection on the importance of COOPANEMA for local social and economic development. We used qualitative and descriptive methodology supported by case studies, interviews, and documentary and bibliographic surveys. The cooperative maintains a participative management, with good administrative quality, thanks to its specialized accounting, technical and legal assistance. We conclude that COOPANEMA is a socially consolidated institution, regarded as a reference in cooperative management, acting in the execution of actions and occupying seats in forums, municipal and regional public policy councils, thus contributing to local development.
\end{abstract}

Key words: Solidarity-based enterprise, participatory management, collective actions, social organization, peasantry.

\section{Introduction}

In the last decade, the Brazilian economy has been suffering from the global economic crisis: "The financial crisis that began in the United States in 2007 and led to the deepest global recession since World War II" (Evans 2011, p. 1) giving rise to forms of solidarity economy that are effected by many social segments, especially through cooperativism (Neves et al. 2019).

In this context, cooperatives and other forms of solidarity organizations began to act with greater incidence, both in markets and in facilitating access to food and protection for vulnerable families, seeking possibilities for marketing their products, collective purchases and provision of various services, which has enabled the insertion of various professionals in the world of work (Neves et al. 2019).

According to Pires (2010), agricultural cooperatives are designed to strengthen the rural production space, as they are alternatives capable of organizing productive activity, expanding the advantages of agriculture in the markets and reviving productive territories. The Cooperativa Mista de Agricultores Familiares do Vale do Ipanema (COOPANEMA), formed by family farmers, corresponds to this conceptualization.

This article aims to present the case of COOPANEMA through a reflection on the importance of this cooperative for the social and economic development of family farmers in the Agreste Meridional region of Pernambuco, Brazil.

Based on this objective, we formulated the following questions: How is COOPANEMA's management carried out? What are its main conflicts? And which of its practices contribute to local social and economic development?

It is worth mentioning that COOPANEMA was chosen for this work because it is considered a reference in the State of Pernambuco - Brazil, as well as due to the ease of access to information. The first and second 
authors, since 1999, provide services to the Cooperative and since 2019, are part of its membership. Therefore, the statements made throughout the article have as reference the experience and effective participation of the authors as cooperative members and active in COOPANEMA.

Furthermore, the board of directors made itself available to the study, facilitating access to information by providing documents and granting interviews to clarify any doubts.

\section{Theoretical Framework}

To organize a mixed agricultural and cattle ranching cooperative, farmers need, in addition to being organized and willing to carry out a collective action, to have various specific knowledge to comply with the legal obligations, required by municipal, state and federal public agencies, aimed at controlling cooperatives, because the legislation is complex and imposes obligations on the operation in a hierarchical network among cooperatives, specific accounting, investment in education and strengthening of cooperativism (Brazil 1971). Registration with the National Network for the Simplification of Registration and Legalization of Companies and Businesses (REDESIM) includes several organs, such as the Board of Trade, City Hall, Federal Revenue Service, Finance Secretariat (SEFAZ) for commercialization, and other licenses depending on the specific activity of the cooperative (Brazil 2007).

The International Cooperative Alliance (ICA) defines a cooperative as "an autonomous association of persons who join together voluntarily to meet common economic, social and cultural needs and aspirations through a collectively owned and democratically managed enterprise" (COOPHESP 2021).

In Brazil the cooperative is an institution legally constituted by specific legislation with regard to its format and specific tax treatment (Brazil 1971).

The basic principles that guide the relationship of the cooperative institution with the members are based on the elaboration instituted by the Rochdale pioneers in 1844 and adapted in some congresses throughout history, being the last revision in 1995 in the "congress commemorating the centenary of cooperativism, held by the International Cooperative Alliance (ICA) [...], previously, other two reformulations, in the ICA Congresses of 1937 and 1966" (Marra 2016, p. 7).

For members to join a cooperative, there must be: 1) Free and voluntary membership; 2) Democratic control by the members; 3) Economic participation of members; 4) Autonomy and Independence; 5) Education, training, information; 6) Cooperation among cooperatives (inter-cooperation); 7) Concern for the community (Marra 2016).

Joining a cooperative requires a preliminary financial investment from the interested parties, whose value for each member is the result of the apportionment of an amount defined by the creators of the cooperative as necessary to start the activities, which includes: obtaining the social capital necessary to open a cooperative and start the work, depositing the shares, paying the fees, covering the costs to manage the institution, hiring legal and accounting services, increasing production and commercialization logistics (SESCOOP 2016).

The cooperativism law also provides guidance on the mandatory nature of the taxes levied on the transactions carried out by the cooperative, distinguishing the actions performed by the cooperative with its members or people outside the cooperative framework (Brazil 1971). This can be seen in charts 1 and 2 below:

Table 1: Federal, state and municipal taxes levied on cooperative activities in 2020.

\begin{tabular}{|l|l|}
\hline SPHERE & \multicolumn{1}{|c|}{ DESCRIPTION } \\
\hline Federal & $\begin{array}{l}\text { Contribution for the Financing of Social Security (COFINS); Income Tax } \\
\text { (IR); Social Contribution on Net Income (CSLL); Social Integration } \\
\text { Program (PIS) - Billing; PIS - Payroll; National Social Security Institute } \\
\text { (INSS) - Rural Producer / Services Taken); Tax on the Circulation of Goods } \\
\text { and Services (ICMS); and Tax on Manufactured Products (IPI) }\end{array}$ \\
\hline State & $\begin{array}{l}\text { ICMS, Tax on Transmission Causa Mortis and Donation (ITCD) - On } \\
\text { donations. }\end{array}$ \\
\hline Municipal & Tax on Services of Any Nature (ISS), Business License Fee. \\
\hline
\end{tabular}

Source: Amorim (2020 s/p). 
Table 2: Federal, state and municipal taxes levied on the activities of cooperatives, with and without cooperative members, in 2020.

\begin{tabular}{|l|c|c|c|}
\hline TAXES / FEES & $\begin{array}{c}\text { COOPERATIV } \\
\text { E ACTION }\end{array}$ & $\begin{array}{c}\text { NONCOOPERATI } \\
\text { VE ACT }\end{array}$ & ALIQUOT \\
\hline IR & No & Yes & $15 \%$ profit \\
\hline CSLL & No & Yes & $9 \%$ profit \\
\hline ICMS & $\begin{array}{c}\text { Yes (sale of } \\
\text { service) }\end{array}$ & Yes & Maximum 5\%. \\
\hline INSS Rural producer & Yes & Yes & $1.5 \%$ A/P invoice \\
\hline $\begin{array}{l}\text { INSS Services rendered }- \\
\text { PF }\end{array}$ & Yes & Yes & Employer 20\%. \\
\hline COFINS & No * & Yes & Retain 11 \\
\hline PIS Billing & No $*$ & Yes & $1,60 \%$ \\
\hline PIS over payroll & Yes & Yes & $1 \%$ Payroll \\
\hline IPI & Yes & Yes & - \\
\hline Generates profit & No & Yes & - \\
\hline $\begin{array}{c}\text { Results may be divided } \\
\text { among partners }\end{array}$ & Yes & No & - \\
\hline
\end{tabular}

Source: Amorim (2020 s/p).

It is also up to the founders of a cooperative to decide which federal tax regime they need to follow (Brazil 1971). The cooperative members can opt for the presumed profit regime, provided that the cooperative does not fall under the conditions of mandatory determination of the actual profit, they only need to forward documentation to the specific sectors in order to obtain tax advantages according to the items that will be produced, such as the reduction of the Tax on Circulation of Goods and Services (ICMS) at the state level, and in the case of institutional marketing by the National School Meals Program (PNAE), obtain exemption for products demanded by the purchasing institution (Amorim 2020).

After being duly registered and instituted, the cooperative must register with national bodies in order to be assimilated and recognized within the framework of the Brazilian cooperative system. The Organization of Brazilian Cooperatives (OCB) is the body that regulates cooperatives in general, accrediting them to operate under the Cooperative Law (Brazil 1971).

In 2005, with the increase in the number of family farmer cooperatives, the National Union of Family Farming Cooperatives and the Solidarity Economy (UNICAFES 2008) was created, considering the need to have a national body with which to identify and discuss their demands.

According to Reisdorfer (Reisdorfer 2014), the OCB understands cooperatives as a social movement, a philosophy of life and a socio-economic model that is capable of reconciling economic growth and social well-being. It also deals with the aggregation of people who cultivate the value of mutual help, responsibility, democratic participation, equality, equity, solidarity, honesty, social responsibility, transparency in management and concern for their peers.

Among the challenges faced by the cooperative is its role of having, at the same time, to develop an efficient organizational process to compete with companies of a capitalist, market-oriented nature, and to maintain a human-centered management system. Therefore, the management design of a cooperative needs to achieve good results in three dimensions: i) Meeting the interests of its members, ii) Achieving good economic results, iii) Having social relevance and the capacity for political incidence in the place where it does business (Zylbersztajn 1994).

The managers of a cooperative institution must follow a plan that details specific goals to meet the cooperative legislation, achieve good economic social and political results, observance and compliance with the items related to its philosophy and the cooperative education processes (Wakulicz and Filho 2015).

The cooperatives insert themselves safely in the mercantile economy, occupying mainly those sectors of activity in which capitalistic intensity remained weak while 
the mutualist organizations are almost entirely incorporated into the non-market economy practiced by the state (França Filho et al. 2020, p. 570).

For Rios (1998), a cooperative must be seen and treated as a modern company, but ensuring it is distinguished from a "mercantilist company". This is because a cooperative is formed by a group of people who seek to achieve results for their development, but its purpose is also to reach other people with the good results achieved.

As the associates are also the owners, there is no exploitation relationship nor centralized capital accumulation. The main way of working is through the organization of teams implemented by the associates themselves in order to establish a win-win relationship.

[...] the difficult task of reconciling the economic and the social in the organizational dynamics of cooperative acts, with market pressures that put pressure on the social utility purpose of the enterprise. In this type of situation a certain compromise in the juxtaposition between social and economic purposes of the enterprise is observed, safeguarded by the internal democratic governance. In other, more critical situations, it is even the principle of democratic governance that is at risk, beyond the primacy of financial viability over social utility, compromising the very cooperative character of the initiative (Rios 1998, p. 571).

Brazilian legislation created its own norms for cooperatives, transforming them into a special management model, which is self-management (Esteves 2013). Therefore, when studying a cooperative, it would be more important to consider the management processes and ways used to achieve its objectives than to simply certify legal and bureaucratic aspects. From this perspective, the main purpose of a cooperative is to meet the collective aspirations of a given community.

It is necessary to understand that its context is not exported from Europe to Brazil and that the notion of social economy in Brazil tends to be restricted to cooperatives which, due to the different ways of accepting or resisting institutional pressures, end up assuming different natures and characteristics. Some, the so-called conventional cooperatives, absorb pressures and adapt to the way they act in the market. Others, the so-called popular cooperatives, resist and privilege the original form of democratic governance(França Filho et al. 2020, p. 571-572).

For Valadares (2002), a cooperative is only organized when members perceive that through cooperation they have achieved their results, which is why it is organized through collective and voluntary agreement of collaboration for the business exercise. Therefore, this aspect is in first place in relation to the entrepreneurial aspect which, in isolation, would not meet individual needs. However, the individual cannot be prioritized in a cooperative management and administration model, since such a model would fail.

The role that cooperatives assume is complex because it is twofold, needing at the same time to focus on the relationship with members and with the markets, which is competitive. This is because the cooperative is obliged by federal law and its bylaws to adopt well defined attitudes, cannot deviate from the principles established by cooperativism, and needs to build an efficient strategic management aligned with its market segment. In practice, this requires personnel who are technically qualified in administration and management, but who are also skilled negotiators, integrity and conflict mediators (Rios 1998; Pires 2010; França Filho et al. 2020).

The daily dynamic of a cooperative is very evident in the power relations, in which there is no central point of governance, but a fluidity of alternation, given the relationship with the members and the relationship with the market, each of which requires specific skills and differentiated awareness.

For Foucault (2008), in power relations there is a set of asymmetric elements, which constantly interact from top to bottom and from bottom to top, sustaining and questioning the instituted powers. This basically occurs by observing three forms of power: i) the power of laws, which attributes to the authority the instituted functions, ii) the power governed by the concept that attributes legitimacy in representation, and iii) the power instituted by morality that accredits, or not, someone to possess authority. 
It is about (...) capturing power at its extremities, in its last ramifications (...) capturing power in its most regional and local forms and institutions, mainly at the point where it goes beyond the rules of law that organize and delimit it (...) In other words, capturing power at the less and less juridical end of its exercise (Foucault 1979, p. 182).

Foucault (1979) further highlights that power relations are constructed in practice throughout history and their forms are constantly changing and fluctuating. Power is not located in any definitively perceived place, nor in a particular person, but rather in the existing relations in society represented by actions on actions in verticalized ascending or descending relations, or from the periphery to the centre and from the centre to the periphery. In turn, the behaviours of the people involved will conform according to what they consider the quality of their "government".

Through this structure we believe it is possible to achieve the main objective expected for this study, which was to understand the operation and strategic importance of COOPANEMA in its operating context.

\section{Methodology}

As highlighted by Yin (2001), the case study can use techniques such as experiments, surveys, historical research and analysis of information in archives, a method that covers everything with planning logic, and preparation in the collection and reading of data.

The relevance of this work lies in discussing the importance of cooperativism for family farming, based on an important cooperative experience that has sought to improve the quality of life of its members over its twenty-three years of existence.

The aim is to outline a cooperative experience as an object of study, considering some relevant aspects to characterize COOPANEMA's strategic and operational functioning. Thus, the research assumes a qualitative character. According to Matias-Pereira (2010), qualitative research considers the relationship between the real world and the subject, not seeking to achieve numerical and statistical standards, since it aims at the qualities of social making. Furthermore, research also assumes a descriptive nature, and that - according to Gil (2008) - aims at describing the characteristics of certain events and phenomena.

In order to achieve such purposes, it was necessary to comply with some paths of research, such as: understanding the cooperative's history, its physical structure, the common objectives for which the cooperative members established it, the goals and the desired results.

Although, "in the sciences, for a long time, the case study was seen as a not very rigorous procedure" (Gil 2002, p. 54), currently, according to Yin (2001), this method is considered adequate to study a contemporary phenomenon, within a real context, where the limits are not clearly delineated.

As the proposal to present this article will be descriptive of a particular situation, that COOPANEMA, inserted in a dynamic social context, where workers linked to the cooperative, both relational among themselves and with institutions that are somehow linked to the needs related to the production and marketing of the products of Family Farming, such as the banking system of credit and organization, especially for marketing. Gil (2002) highlights some items in which the case study methodology is suitable for guiding research and communicating its results:

Hence, then, the growing use of the case study within these sciences, with different purposes, such as: a) to explore real-life situations whose limits are not clearly defined; b) to preserve the unitary character of the object studied; c) to describe the situation of the context in which a given investigation is being conducted; d) to formulate hypotheses or develop theories; and e) to explain the causal variables of a given phenomenon in very complex situations that do not allow the use of surveys and experiments (Gil 2002, p. 54).

Gil (2002) further adds that there are situations in which the case study offers some advantages:

[...] a) its ability to stimulate new discoveries, due to the flexibility of planning and the technique itself; b) the possibility of viewing the whole, its multiple facets; and c) 
the simplicity of applying the procedures, from data collection to data analysis (Gil 2002, p. 60).

The bibliographical survey, to compose this work, was conducted from articles and books related to the topics addressed. The aim was to update the theory and delimit the concepts used in the discussions of this article. It was also necessary to carry out a documental survey, which was made from COOPANEMA's documents, by-laws and plans.

\section{Results And Discussion}

\subsection{Historical aspects and consolidation of COOPANEMA}

COOPANEMA is the result of a long journey made by family farmers, with activities concerning the world of agricultural production with emphasis on participative management.

The first steps in the journey date back to mid-1994, when many family farmers approached the Secretariat of Agricultural Policies of the Águas Belas Rural Workers' Union (STR) with a view to accessing the National Program for the Strengthening of Family Farming (PRONAF).

At the time, according to the founding members, the Secretariat, which had been created with the aim of organising the demand for credit, production and commercialisation, took advantage of the moment and began discussions about the need to set up a cooperative. But it was in August 1997 that a group of 50 members, made up of family farmers and milk producers, founded COOPANEMA. However, the members' access to PRONAF only occurred in 1998, after many internal discussions about the real need for credit, its benefits and responsibilities. And only after overcoming the resistance of the Banco do Nordeste do Brasil (BNB), Garanhuns Agency - PE, which took a long time to understand the peculiarities and aptitudes of the region, in addition to dairy farming, began to also finance sheep and goat farming.

The financing was released by BNB individually, with the collective guarantee, without the need to use COOPANEMA's guarantee fund, despite the fact that COOPANEMA had organized the farmers and prepared all the projects.

In 2001, as experienced by the authors since 1999, the deadline to pay off the first installments of the financing expired, when a generalized default was verified, which caused great frustration for the cooperative members. The situation was analyzed at the time by COOPANEMA's direction, which attributed the lack of technical assistance and the great drought that started in 1998 as the main causes of default. The lack of rain lasted until the end of 2003, causing commercialization difficulties due to lack of production volume and poor product quality. In this period, several proposals to sign contracts for the purchase of raw materials were refused by the cooperative, given the limitations imposed on production, a fact that greatly discouraged the members.

However, COOPANEMA continued its sensitization work over the years, seeking to structure its membership, stimulating the participation of young people and women, organizing the production of members through qualified technical assistance, and awaiting the arrival of new opportunities. And in March 2004 , the process of restructuring the milk production chain was put into practice with effective organization of production and commercialization of raw milk type "C".

In 2007 COOPANEMA already had 298 members, each established in a Family Production Unit (UPF). The LGUs had diversified production, which included, in addition to milk, specific products under the governance of women, such as small animals and fruit. Moreover, thanks to the work done with young people, this dynamic has been accentuated and consolidated, making the Cooperative an important space for social inclusion in the municipality.

COOPANEMA currently operates a total collection of 600,000 liters of milk per day through twenty-one nuclei distributed in four municipalities of Pernambuco: Águas Belas, Itaíba, Iati and Tupanatinga. Each nucleus is composed of a physical structure with a milk cooling tank properly conditioned, allowing longer time between milking and collection from the dairy.

Before becoming members and joining COOPANEMA, the farmers suffered constant losses and discarded milk, worked individually and in small volumes, and were subjected to and hostage to the economic variables of the production market. In addition, these producers marketed their production to middlemen, who paid far below the market price for the product. In this sense, the direct sale to dairies, the improved quality of the milk and the greater volume offered reduced vulnerability and added value to their product. 
The work methodology of COOPANEMA's team is based on social equity. Because there is no way to defend the principles of Sustainable Development, without the unfolding of its exercise also in practice. In this sense, the participation of members in COOPANEMA's decisions is not only extremely necessary, but also respected.

To ensure the actions, the board of directors and technicians responsible for technical assistance and management of the milk collection/receipt centers monitor once a week. This occurs at the time of payment of producers supplying milk or other products, in the form of an informal assembly, but representative, in order to pass on information, level understandings and listen to the demands of producers.

Economic efficiency is a constant in the daily routine of the Cooperative, which peremptorily seeks improvements in the results of its assets as its main aggregative goal. This efficiency, however, would not fulfill its cooperative mission if it did not observe other factors linked to management, such as the culture of cooperation, the adequacy of production by each member, and strategic negotiations.

Environmental preservation is not a utopia for COOPANEMA, but a constant need. This is because the cooperative members understand that there is no way to work with family farming without due care with regard to non-renewable natural resources. Therefore, the associated families are duly prepared regarding the risks encountered in relation to the lack of care with the environment.

Such attitudes concern the various aspects of environmental degradation that directly impact the quality of life and economic losses for farming families, such as: erosion and weakening of the soil, loss of genetic resources, reduction of native plants, reduction of water by deforestation, loss of soil and the appearance of stones on the slopes, as well as the contamination of milk by pesticides and/or medicines.

Finally, it is worth stressing that COOPANEMA's role has been that of an inducer and facilitator agent of the rural development process, besides the fact that it represents an animator and articulator agent of the decisions and the execution of the defined actions. For that, it counts on a specialized multidisciplinary team that attends both the internal and external public, under service provision contracts, as ruled by the Cooperative interests.

\subsection{Management of COOPANEMA}

COOPANEMA's Statute defines as deliberative instances, four Social Bodies: General Assembly, Administrative Board, Supervisory Board and Ethics Board.

The General Assembly is the supreme organ, as defined in Article $19^{\circ}$ :

Art. 19 - The General Cooperative Assembly, Ordinary or Extraordinary, is the supreme organ of the Cooperative and, within the limits of the Law and these Bylaws, shall take any and all decisions of the Cooperative and its resolutions shall bind everyone, even if absent or disagreeing (COOPANEMA 2014, p. 9).

The Administrative Board is defined in Article $37^{\circ}$ :

Art. 37 - Board of Directors comprised of 05 (five) members, all cooperative members, with the titles of President, Vice President, Administrative and Financial Director, Technical and Operational Planning Director and Commercial and Industrial Director, elected by the General Assembly, for a term of 03 (three) years, being mandatory, at the end of the mandate, the renewal of at least 1/3 (one third) of its components (COOPANEMA 2014, p. 14-15).

The Audit Board has its function and composition defined in Article 50 :

Art. 50 - The Cooperative's administration must be accompanied, guided and inspected, assiduously and thoroughly, by a Fiscal Council, comprised of 3 (three) effective members and 3 (three) substitutes, all cooperative members, elected annually by the General Assembly, only 1/3 (one third) of its members being eligible for reelection, whose main function shall be to report to the other cooperative members on the conclusions reached during the fiscal year, recommending or not the approval of the accounts for the period (COOPANEMA 2014, p. 23). 
The Ethics Council is in charge of settling conflicts from an ethical point of view, as stated in Article $63^{\circ}$ :

Art. 63 - The Cooperative's administration must be regularly and thoroughly monitored and oriented by an Ethics Council, comprised of 3 (three) effective members and 3 (three) substitutes, all cooperative members, elected for a term of 3 (three) years by the General Assembly, with only 1/3 (one third) of its members being eligible for reelection, whose main function shall be to settle conflicts of an ethical nature and discipline the behavior of the cooperative members, as well as its guiding policies (COOPANEMA 2014, p. 30).

COOPANEMA Social Statute also ensures that once a year a General Assembly is held for the rendering of accounts, election of the Audit Committee, evaluation and planning. The methodology adopted is the dialogued exposition, i.e., the doubts are clarified and the suggestions brought by the associates are registered by the team of directors, so that they can be part of the elaboration of strategies and more detailed planning before the due adjustments for the implementation of new actions.

The monitoring of actions is carried out throughout the year in ordinary or extraordinary meetings that coincide with the milk payment day, which occurs once a week. As the payment is made individually, while one producer is being attended to, the others remain in the auditorium talking to the board.In this context, COOPANEMA adopts an appropriate methodology that ensures the inclusion of its members as protagonists in all stages, from milk production and commercialization to institutional management. This practice coincides with or precedes the current proposal of the ATER methodology suggested by the National Policy on Technical Assistance and Rural Extension for Family Agriculture and Agrarian Reform, as stated in Law No. 12.188 of 11 January 2010, which deals in its Article $3^{-}$the principles of the National Policy on Technical Assistance and Rural Extension (Pnater) and which suggests in its item III the: "Adoption of participatory methodology, with a multidisciplinary, interdisciplinary and intercultural approach, seeking the construction of citizenship and the democratization of public policy" (Brazil 2010). The adoption, in practice, of the attitude of "thinking by doing" - doing and thinking should be the strategy to be observed in daily life, because it is in concrete relationships that learning takes place, is reproduced and improved (Brazil 2010). The formative focus is the family as the protagonist in the production processes, so that the UFP is the visible reflection of the skills and competences assimilated by the family and this practical result, in a permanent process of self-assessment, is the formative object and always (re)modeled by actions coming through systemic thinking/ reasoning, always improved.

For this, the dimensions of human formation that give meaning to their multiple existences are observed: affective-emotional, intellectual-cognitive and attitudinal-entrepreneurial (La Taille et al. 1992; Dolabela 2017). In practice, the methodological process adopted by COOPANEMA to respond to its learning needs presupposes achieving a broadening of consciousness that ensures new looks, and this is important that it takes place in three inseparable dimensions that are interconnected for decision making: 1) The family, 2) The community and 3) Public power.

The approach to gender and generational issues is brought up in the debates and, in principle, in cases in which a conformation already given by culture is observed, in which the roles are already well defined, there is problematization to produce reactive attitudes to face the problem (Freire 2002).

In the traditional context, the role of men ends up being dominant, since they have control of the means and processes of production, while women, as well as children, adolescents and young people have no power of decision, remaining - almost always - on the margins of decisions and processes, acting almost always as assistants to the men in production: 1) the man is responsible for doing field work (outside the home), doing business, providing for the home and taking care of the infrastructure of the property (constructions, renovations); 2) the woman is responsible for domestic chores and taking care of small animals and plants in the home yard and also childcare; 3) young people are responsible for studying and helping their parents, depending on their gender.

Although this reality seems obvious and accepted, it ends up being a hindrance to the development of the UPF - and to society - because by denying the participation of women, children, adolescents and youth in decisions and in the construction of changes, there is a social exclusion and, therefore, an injustice. This has caused situations to unleash that generate "collective" damage because it ends up losing the potential of intelligence and creative work of women and young people, and extends to the collective (community and 
public power) that still shows signs of not being embarrassed or indignant about social injustices and exclusions.

One of the main consequences of this model is the lack of interest among young people in remaining in the field, hindering family succession and the underutilization of the capabilities of women who, when there is room for participation, play an important role, especially in milk processing.

In practice, the role of women goes beyond the "obvious", because they have knowledge that goes beyond the apparent role of reproducing energy to maintain the active production of men. They are included in production through various fronts not considered "of value", although they are often equated with men's production or in some cases even more significant. However, the male presence in COOPANEMA assemblies is evident.

It is quite evident the reality of young people, children of the cooperative members, today critical of the current production model to which they have difficulty or lack of interest in joining, to escape this reality of which they do not feel part, or have no space to generate their own income, they seek jobs in cities. Added to this are the concepts imposed by the school culture that the ideal for the youth would be to get an education and graduate in order to leave the countryside and have a better life than that of their parents, since life in the countryside is transmitted as being "something without a future". The hard work in the fields and the low remuneration are also causes for their leaving.

However, today there are more appropriate management technologies (agroecological/agropastoral) that provide less physical effort and better results, as well as chances to make an organization of production considering all links in the production chains, but these technological resources unfortunately are not yet part of the lives of these small producers; but that could bring them gains and better living and working conditions. We also detected that many young people are interested in putting some of these experiences into practice, coming up against the resistance of parents who insist on remaining in the traditional model - for them - the most reliable, since they have historically guaranteed them the support of their families. On the one hand, this is not meaningless, since parents would rightly be insecure with the uncertainties of novelty. On the other hand, this closure to the new has a highly detrimental result, since it does not allow advances in the processes and prevents the self-inclusion of the children in the property.

To address this, gender and generation issues are addressed at all times and stages of the cooperative's planning, with the aim of including all members of the family in the entire productive system and farm dynamics.

With this, COOPANEMA thought to have established its political and pedagogical basis for the development of associative and solidarity-based forms of co-responsibility that help in good coexistence and that favor relationships based on equity, mutual collaboration, improvement of people's self-esteem, and strengthening of groups in favor of social transformations.

To this end, the training processes take place through the preparation of the team of technicians who advise the families in the UFP, the moderation of meetings and producers' meetings, aiming at interaction with public authorities and local institutions.

For women, specific methodologies are developed to encourage collective organization for production and commercialization, mainly with the aim of increasing existing activities, such as the production of milk derivatives - such as sweets, curd cheese, etc. -, and other artisanal, textile and culinary products.

Meetings are held with women, focusing on relevant topics of interest to them, according to their selfperception as "women living in rural areas", in order to enhance their self-esteem by playing an affirmative role as protagonists in the milk production chain and other activities.

For young people, a methodology is used that encourages their direct engagement in the management of the UFP, mainly by linking them to the creation/adaptation and adoption of new production technologies, environmental preservation and management (administration and control of physical, financial and technological resources), including knowledge of sectoral public policies and the procedures to access them, as well as stimulating a systemic view of the milk production chain and the ability to interact with actors linked to the chain, the expansion of negotiation skills and the ability to interact in the sector's collective organizations. As shown in the study conducted in 2018 by Santos:

In the region's dairy sector, the only case of a cooperative that was successful in its foundation and management was the Cooperativa Mista dos Agricultores Familiares do Vale do Ipanema (COOPANEMA), located in the municipality of Águas Belas. 
Founded in 1997, this cooperative is pointed out by both producers and representatives of IPCs as an exception to the rule observed in the region, being a fruit of hard work by the members and the collective strengthening that was developed local leadership (Santos 2018, p. 77).

\subsection{Physical structures and organisation of personnel}

Currently, 170 cooperative members dedicate themselves to their UFP in the production of milk and other products, especially food, being the Cooperative in charge of providing technical assistance, sorting, quality control of the products and implementing logistics for the commercialization of the production.

COOPANEMA's management model conferred in productive terms an approximate volume of a production of 650,000 liter milk/month, although currently it is around 390,000 liter milk/month. This considerable decrease is a reflection of the last great drought that began in 2009 and lasted until 2017 (Martins and Vasconcelos Junior 2017). In this period the cooperative members faced significant losses of herd, so that many abandoned the activity and those who remained, have not yet fully recovered from this crisis.

COOPANEMA's main source of resources is the donation of $\mathrm{R} \$ 0.10$ per liter of milk delivered to the Cooperative to be commercialized, where $\mathrm{R} \$ 0.07$ are used to maintain COOPANEMA itself and the other R\$ 0.03 are used to maintain the milk cooling tanks.

The cooperative has a veterinary pharmacy that distributes medicines and other veterinary products to the member families at cost price. At its headquarters, there is a warehouse for the distribution of different varieties of animal feed.

Technical assistance and rural extension (ATER), provided by COOPANEMA's technical team to associated families, includes several technical visits for participatory diagnosis and planning of the UFP, as well as guidance on the organization of production, processing and marketing, besides providing tools for the control of cooling tanks, the reception and storage of milk in the tanks and the coordination of commercial relations with dairies.

Among the work conducted in the field for the members, the veterinary and zootechnical technical assistance is a constant and takes place through visits and internet contacts, especially WhatsApp. Furthermore, throughout the year, training workshops are given on various other topics, such as animal nutrition, vaccines, artificial insemination, the production of bulk, the care of calves, the hygiene of management environments, zootechnical control, hygienic milking, cooperative training, marketing, the milk production chain, the diversification of production, as well as specific training for women's groups.

One of COOPANEMA's major concerns is to make available adequate means for producers to carry out genetic improvement of dairy herds in the region, using artificial insemination and embryo transfer techniques. Another major concern revolves around the production of forage palm, corn and sorghum.

Currently, the cooperative is encouraging families to adopt the species of leucena (Leucaena leucocephala), gliricídia (Gliricidia sepium) and moringa (Moringa oleifera) as sources of protein to replace soybean meal (Glycine Max), corn (Zea mays subsp. Mays) and cottonseed (Gossypium).

There is an effective support to the commercialization of the products in annual and monthly fairs. COOPANEMA promotes a large Family Farming Fair every year. The cooperative identifies, sensitizes, mobilizes and organizes member families; negotiates with partners who support the fair; organizes logistics and structures the fair's environment; transports the products of member families to the fair; and effectively coordinates the fair.

COOPANEMA also maintains a monthly Family Farming Fair with fruit and vegetables and handicrafts in the municipality of Águas Belas - PE, constantly mobilizing fruit and vegetable growers and artisans, as well as providing the stalls and negotiating the location of the fair with the municipality.

Marketing support is also provided for access to institutional markets, such as the Food Purchase Program (PAA) and the National School Meals Program (PNAE). COOPANEMA identifies suppliers from among its members, negotiates product quantity and quality, collects the purchased items and delivers them to previously agreed locations.

In 2017, COOPANEMA joined the Program for the Production and Diffusion of Innovations for the Competitiveness of Local Productive Arrangements of the State of Pernambuco Dairy Products (PROAPL), started to contribute to the implementation of the Local Productive Arrangements (APL) Competitiveness Improvement Plans and to execute the application of information and communication technologies with the adoption of the monitoring and evaluation system of the Program's activities. 
COOPANEMA's Cooperative members have participated in international exchanges with producers from different countries, involving themes related to the sector: Argentina, development of the milk production chain and cooperativism; France, milk production chain in innovative processes and cooperativism; Portugal, cooperativism and food production.

COOPANEMA represents its members in different forums and councils, in which it effectively participated: Águas Belas Municipal Council for Sustainable Rural Development (CMDRS), Águas Belas Municipal Health Council, Águas Belas Municipal Education Council, Pernambuco's Agreste Meridional Territorial Development Commission (CODETAM), Articulação Semiárido Brasileiro (ASA), Comitê Estratégico da Pernambuco da Pecuária Leiteira (CEPLEITE), Gabinete da Palma, Rede de Sementes Crioulas do Agreste Meridional de Pernambuco (SEMEAM Network), Rede Agreste de Agroecologia de Pernambuco (REAGRO), Grupo Territorial de Governança (GTG): Production Chain of Milk, Beans, Goats and Sheep, and Roots and Tubers.

\section{Concluding Remarks}

This article sought, through a case study on COOPANEMA, to reflect on its importance for the social and economic development of family farmers in the Agreste Meridional region of Pernambuco.

We observed that COOPANEMA is made up of family farmers dedicated to the production of milk, but also of fruits, vegetables, roots and tubers, besides aggregating professionals from several areas, such as administrators, veterinarians, zootechnicians, agronomists, agroecology technicians, accountants, lawyers, among many others, who meet its needs with the internal and external public.

Based on the actions verified in this study we can see that COOPANEMA contributes significantly to local development, to the extent that it strives to improve the quality of life of its members in the municipalities of Águas Belas, Iati, Itaíba and Tupanatinga, by promoting improvements in the genetic quality of the cattle herd; by participating in discussions about public policies as a member of sectoral councils and regional forums, representing family farming. Moreover, promoting, not only the development of family farming, but of the community in general.

The Cooperative pays constant attention to social and environmental responsibility, promoting the transition from traditional forms of production to agro-ecological ones in an attempt to involve youth and local women. COOPANEMA invests heavily in training courses for family farmers in order to promote continuous qualification, both in terms of the administration of the UFP and in terms of improving production techniques. It also participates in international exchanges in the search for appropriate technologies for family farming and cooperative development.

Thus, the Cooperative maintains a participatory management, with good administrative quality, thanks to its specialized accounting, technical and legal assistance. There is an effective participation of the cooperative members through monthly meetings in the milk production nuclei and with farmers from other APL, such as horticulturists, fruit growers and artisans. Thus, it is perceptible the consistency of the cooperative principles in the exercise of the members of the Administrative Council, as well as the members in their internal and external relationships, which is why COOPANEMA is recognized in the state of Pernambuco as the "reference cooperative" of the Agreste Meridional.

\section{References}

1. Amorim AR (2020) Cooperativismo Sustentável. Ascon, Fortaleza. https://drive.google.com/file/d/18UbuXhXND0AX_0p9rYSnCPs61oJY2xA-/view?usp=

2. Brasil (1971) LEI N. 5.764 DE 16 DE SETEMBRO DE 1971. Diário Oficial [da] República Federativa do Brasil, Brasilia. http://www.planalto.gov.br/ccivil_03/leis/15764.htm

3. Brasil (2007) LEI $\mathrm{N}^{0} 11.598$ DE 3 DE DEZEMBRO DE 2007. Casa Civil, Brasilia. http://www.planalto.gov.br/ccivil_03/_ato2007-2010/2007/lei/111598.htm

4. Brasil (2010) LEI $\mathrm{N}^{\circ} 12.188$ DE 11 DE JANEIRO DE 2010. Casa Civil, Brasilia. http://www.planalto.gov.br/ccivil_03/_ato2007-2010/2010/lei/112188.htm

5. COOPANEMA (2014) Estatuto Social. Cooperativa Mista dos Agricultores do Vale do Ipanema, Águas Belas.

6. COOPHESP (2021) Identidade Cooperativa. In: NEO INTERNET. http://www.coophesp.com.br/site/cooperativismo/identidade-cooperativa/. Accessed 30 out 2021

7. Dolabela F (2017) Pedagogia Empreendedora, 2a . Editora de Cultura, São Paulo 
8. Esteves EG (2013) “Todos são iguais", "todos são responsáveis" e "todos estão no mesmo barco": os (des)entendimentos da autogestão cooperativa. Cad Psicol Soc do Trab 16:135-148. http://pepsic.bvsalud.org/pdf/cpst/v16n1/a11v16n1.pdf

9. Evans T (2011) Cinco explicações para a crise financeira internacional. Rev tempo do mundo - rtm 3:9-30. http://repositorio.ipea.gov.br/bitstream/11058/6248/1/RTM_v3_n1_Cinco.pdf

10. Foucault M (2008) Segurança, território, população: curso dado no Collège de France (1977-1978). Editora Martins Fontes, São https://www.academia.edu/14856834/Foucault_Michel_Aula_de_8_de_fevereiro_de_1978_Seguran \%C3\%A7a_Territ\%C3\%B3rio_e_Popula\%C3\%A7\%C3\%A3o_curso_dado_no_Coll\%C3\%A8ge_de _France_1977_197

11. Foucault M (1979) Microfísica do poder. Edições Graal, Rio de Janeiro. https://edisciplinas.usp.br/pluginfile.php/5501197/mod_resource/content/2/12_Foucault_Microfisica. pdf

12. França Filho GC de, Rigo AS, Souza WJ de (2020) A reconciliação entre o econômico e o social na noção de empresa social: limites e possibilidades (no contexto brasileiro). Organ Soc 27:556-584. https://doi.org/10.1590/1984-9270948

13. Freire $P$ (2002) Pedagogia da Autonomia: Saberes Necessários à Prática Educativa, $25^{\circ}$ edn. Paz e Terra, São Paulo. http://www.apeoesp.org.br/sistema/ck/files/4\%20Freire_P_\%20Pedagogia\%20da\%20autonomia.pdf

14. Gil AC (2002) Como elaborar projetos de pesquisa, $4^{\mathrm{a}}$. ed. Atlas, São Paulo. https://home.ufam.edu.br/salomao/Tecnicas\%20de\%20Pesquisa\%20em\%20Economia/Textos\%20de $\% 20$ apoio/GIL, \%20Antonio\%20Carlos\%20-

$\% 20$ Como\%20elaborar\%20projetos\%20de\%20pesquisa.pdf

15. Gil AC (2008) Métodos e Técnicas de Pesquisa Social, 6 ${ }^{\mathrm{a}}$. ed. Atlas, São Paulo. https://docero.com.br/doc/nxs 1 n8x

16. La Taille Y de, Oliveira MK de, Dantas H (1992) Piaget, Vygotsky, Wallon - teorias psicogenéticas em discussão. Summus, São Paulo. https://petpedufba.files.wordpress.com/2016/02/piaget-vygotskywallon-teorias-psicogeneticas-em-discussao-1.pdf

17. Marra A (2016) Doutrina cooperativista. In: e-Tec Brasil - Associativismo e Cooperativismo. SESCOOP-RN, Natal, p p198.http://proedu.rnp.br/bitstream/handle/123456789/578/Aula_05.pdf? sequence=9\&isAllowed=y

18. Martins ESPR, Vasconcelos Júnior F das C (2017) O clima da Região Nordeste entre 2009 e 2017: monitoramento e previsão. Parc $\quad$ Estrat http://seer.cgee.org.br/index.php/parcerias_estrategicas/article/viewFile/846/774

19. Matias-Pereira J (2010) Manual de metodologia da pesquisa cientifica, $2^{\circ}$ edn. Atlas, São Paulo

20. Neves M de CR, Castro LS de, Freitas CO de (2019) O impacto das cooperativas na produção agropecuária brasileira: uma análise econométrica espacial. Rev Econ e Sociol Rural 57:559-576. https://doi.org/10.1590/1806-9479.2019.187145

21. Pires MLL e S (2010) O Cooperativismo Agrícola Como Uma Forma de Neutralizar as Desvantagens Competitivas da Agricultura Familiar. Em análise a Coopercaju. XXXIII Congr. Bras. Ciências da Comun. 1-15. http://www.intercom.org.br/papers/nacionais/2010/resumos/r5-2786-1.pdf

22. Reisdorfer VK (2014) Introdução ao cooperativismo. Universidade Federal de Santa Maria, Santa Maria.

https://www.bibliotecaagptea.org.br/administracao/cooperativismo/livros/INTRODUCAO\%20AO\% 20COOPERATIVISMO.pdf

23. Rios LO (1998) Cooperativas brasileiras: manual de sobrevivência \& crescimento sustentável. STS, São Paulo

24. Santos VH da S (2018) Representações sociais sobre o processo de certificação da indicação geográfica do queijo de coalho no agreste de Pernambuco. UFRPE. http://www.padr.ufrpe.br/sites/default/files/testes-dissertacoes/VICTOR HUGO SANTOS.pdf

25. SESCOOP (2016) Guia para dirigentes de cooperativas.

26. http://www.goiascooperativo.coop.br/arquivos/downloads/guia-de-dirigentes-de-cooperativas19923.pdf. Accessed 30 out 2021 
27. UNICAFES (2008) Estatuto Social.

28. http://cirandas.net/articles/0011/5053/estatuto_unicafes.pdf. Accessed 30 out 2021

29. Valadares JH (2002) Moderna administração de cooperativas. SESCOOP/GO, Belo Horizonte. https://www.docsity.com/pt/administracao-de-cooperativas/4830591/

30. Wakulicz G, Filho JT de O (2015) Legislação Cooperativista. Colégio Politécnico - UFSM, Santa Maria. https://central3.to.gov.br/arquivo/453269/

31. Yin RK (2001) Estudo de caso: planejamento e métodos. Bookman, Porto Alegre. https://docero.com.br/doc/ssx00ss

32. Zylbersztajn D (1994) Organização de cooperativas: desafios e tendências. RAUSP Manag J 29:2332. http://www.spell.org.br/documentos/download/18557 